\title{
Corporate finance in the system of economic analysis management and intensification
}

\author{
Guzaliya Klychova ${ }^{1}$, Alsou Zakirova ${ }^{1,{ }^{*}}$, Gamlet Ostaev $^{2}$, Vyacheslav Sokolov $^{2}$, and Elena \\ Nekrasova $^{2}$ \\ ${ }^{1}$ Kazan State Agrarian University, 65, Karl Marx str., 420015, Kazan, Russia \\ ${ }^{2}$ Izhevsk State Agricultural Academy, 11, Studencheskaya str., 426069, Izhevsk, Russia
}

\begin{abstract}
The study of the issues of assessing the indicators of efficiency and intensification of finance in the activities of corporations operating in modern economic conditions is necessary and relevant. The research was conducted in order to identify a group of financial and economic indicators for assessing the financial efficiency of the corporation. In the course of the research a toolkit was developed, which is a group of indicators that allow corporations to analyze financial and economic activity in generalized and detailed forms. When selecting the resulting and factor indicators of efficiency and intensification, the author's position was based on taking into account the current economic situation, namely, the multiprofile activities of corporations (within and outside the state borders) and the high proportion of borrowed capital for business processes in the core and non-core types of entrepreneurship. The objects of the study in generalized and detailed forms were direct and indirect profitability. They refer to the resulting indicators of efficiency, calculated by comparing the profit and consumed capital. The formed indicators fully correspond to the modern economic situation and the economic nature of the categories of «efficiency» and «intensification». With their use it is possible to calculate the dependence not only between the resultant and factor indicators, but also to analyze the interaction of the factor indicators themselves. These factor indicators meet all the economic postulates and are fully adapted to the generally recognized economic requirements, in particular, financial and economic and financial management. The proposed approach will help to maximize the financial benefits through an objective analysis of the effectiveness and intensification of economic operations.
\end{abstract}

\section{Introduction}

Modern conditions of economic management are inherent in the diversification of economic processes, covering almost all countries (states) of the world, due to global (international) problems of mankind, which are constantly exacerbated due to active overall demographic growth. In this regard, the role of big business in the system of national and international economic relations is the most relevant, because it is large organizations (widely specialized domestic and foreign enterprises) and associations (joint ventures - JV,

\footnotetext{
* Corresponding author: zakirovaar@mail.ru
} 
transnational corporations - TNC) have the maximum synergistic potential to meet the needs of the population in material and non-material goods required for a full life and, thus, thereby, to maintain political stability in states [1-4].

The above means that the basis of the economic well-being of the corporation is their sustainable functioning. At the same time, the management of such large organizations and associations should pay special attention to the efficiency and intensification of corporate finance, since it is the financial economy and financial management in conditions of commodity-money relations that is the central link (core) of business processes carried out by corporations, so the key role in our study belongs to the formation of indicators for assessing the financial performance of the corporation [5-7].

The author's study is based on the works of scientists dealing with the problems of cost evaluation of effective and intensive use of capital, the main business factor of cash flows forming the comparable result (profit) and costs (expenses), and is focused on creating tools for corporations that allow objective analysis of the achieved levels of performance and cost, affecting the dynamics of profit and costs [8-10].

There is a clear trend towards comprehensive research in studies of entrepreneurship, combining the collection and analysis of microdata with the analysis of macroeconomic indicators, the understanding of the subject of research is deepening $[11,12]$. Today, the management of liquidity, financial cycle and profitability of the enterprise occupies a significant share in the financial planning of the organization [13-15]. Questions about the relationship between capital and financial resources may be of some interest [16, 17]. Capital is understood as a part of financial resources, which is invested in the assets of the organization in order to generate income $[18,19]$. Financial resources are capital, which, when invested in economic activities, generates income. Investment is defined as the cost of money aimed at the reproduction of capital, its maintenance and expansion [20-22]. In the most general formulation - it is the investment of temporarily free money in various forms of financial and material wealth in order to make a profit. Economic profit is determined by multiplying invested capital by the difference between the return on invested capital (ROIC) and the weighted average cost of capital (WACC).

The level of quality of corporate governance affects the decision-making on the possibility of capital investment in the company, affects its capitalization. The basic method of increase of capital of corporation - capitalization of net profit The capital attracted for external financing of corporation can be conditionally divided into equity (own) and debt (borrowed) [23-26].

The final desirable reference point of the author's research consists in formation of indicators of efficiency and intensification of corporation finances, revealing the degree of influence on them of efficiency and cost of resources consumed in the course of activity, which serve as indicators for objective assessment of business quality (Fig. 1)

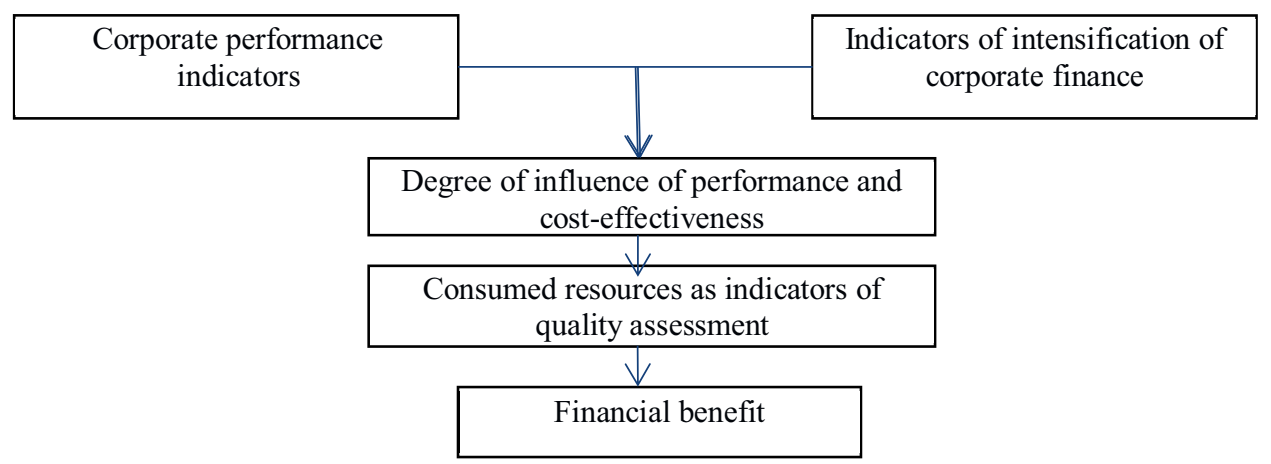

Fig. 1. Formation of indicators of efficiency and intensification of finance of corporations. 
Intermediate desirable milestones to achieve the goal of the research - the generalization of provisions in terms of understanding the essence and content of the categories of «efficiency» and «intensification» at the micro level, the construction of dependencies between the desired resultant and factor indicators and justification of the consistency of the tools proposed in the article.

Any effective result, especially in the commercial sector, which is the core of the national economy, where the main link is corporations, representing the sphere of big business and taking leading positions in it, should be achieved primarily through qualitative (intensive) changes of factor indicators affecting the performance and costs, in other words, capital-saving policy in contrast to the policy of capital increase in terms of rationalization of cash costs [27-29]. At the same time, the intensive indicators themselves, which characterize the effectiveness of activity (efficiency and cost effectiveness) of economic subjects, including corporations, which are the subject of our study due to their importance mentioned above, affect the change in the result and costs (profit and expenses, according to the subject under study) in dynamics. Consequently, the circulation of monetary capital is accompanied by a two-way (reverse) relationship between efficient and intensive functioning of corporations, and therefore, from the author's point of view, they need a system of indicators, with which in general and in particular can assess intensification, draw objective conclusions and conduct measures to optimize it in the field of financial relations

\section{Materials and Methods}

To achieve the goal and solve the problems of the study, the deductive and inductive methods and techniques with elements of economic and mathematical analysis were chosen. These methods allow to carry out calculations of indicators of efficiency and intensification of corporate finances with the maximum possible accuracy, and also to reveal in detail a degree of influence of the resultant indicator on the final result through a set of additive, multiplicative and multiple dependences.

In the established scientific interpretations, the efficiency is understood as the ratio of the result and costs, which, from the author's point of view, corresponds to its content in the study of financial, economic and financial management aspects. It is necessary to know how much the result covers the costs incurred, especially in cases where there is a high probability of unforeseen costs that reduce accounting profit and deflect it from economic profit due to imputed (alternative) costs [30, 31].

The system of indicators of intensification of corporations is determined by a wide specialization and scale of their activities, due to which in its construction we will be guided by numerous economic processes (controllable conditions) and micro and macro environment (uncontrollable conditions) characteristic of big business. It is these groups of economic conditions, which require appropriate monetary costs, and are the basis of the toolkit for the formation of the system of corporate finance intensification indicators (changes in profits and changes in costs under the impact of performance and cost indicators) along with the property of inverse proportionality of direct and indirect efficiency of financial relations (Figure 1) 


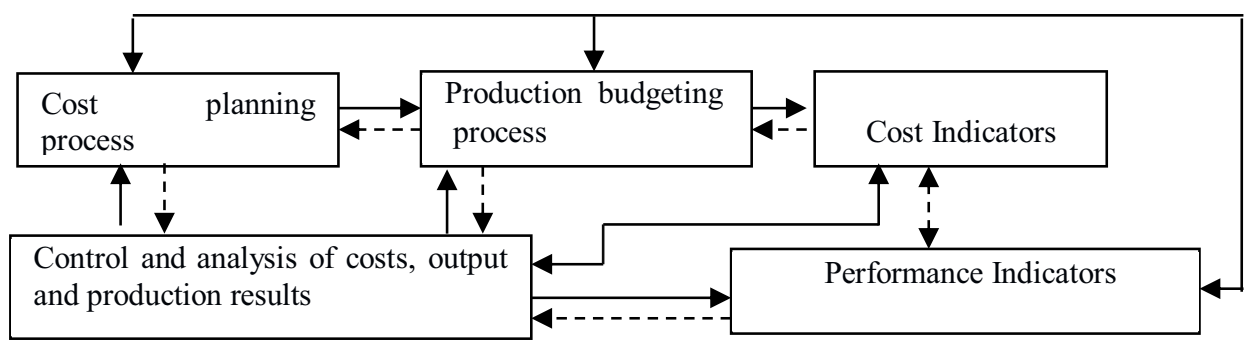

Fig. 2. Formation of the system of indicators of intensification of corporate finance (author's elaboration).

Let's introduce essentially new concept - a transition point to management of corporate finance of micro environment and macro environment.

«Transition point to management of corporate finance of micro- and macro environment» - economic category represents a set of economic relations proceeding in system of management of the corporation according to controllable and uncontrollable conditions.

Taking into account all these circumstances, let us compile intensification indicators, bringing them into a single (integral) system.

Let us start the algorithm of actions with the general indicators of corporate finance efficiency, the leading part of their intensification (formulas (1), (2))

$$
E F_{c f(s)}=\frac{C P}{C E}=\frac{1}{C P / C E},
$$

where, $E F_{c f(s)}$ is the aggregate direct efficiency of corporate finance;

$\mathrm{CP}$ - total corporate profits, rubles;

$\mathrm{CE}$ - total cooperation of expenditures, rubles;

$$
E F_{c f(c)}=\frac{C P}{C E}=\frac{1}{C P / C E},
$$

where, $E F_{c f(c)}$ - total indirect efficiency of corporate finance;

$\mathrm{CP}$ - total corporate profits, rubles;

CE - total cooperation of expenditures, rubles;

Since the aggregate profit of corporations is the difference between their aggregate income and aggregate expenditures from basic and supporting activities, and the aggregate expenditures they calculate consist of the costs of conducting economic processes and adapting to the conditions of the micro and macro environment of activity, ratios of intensification without regard to differentiation of the affecting efficiency (formulas (3), (5)) and with its consideration (formulas (4), (6)) take the following form

$$
\Delta I_{f}=\left[\frac{C P_{1}}{E b p 1+E m i 1+E m a 1}-\frac{C P_{0}}{\text { Ebp0+Emi0 +Ema0 }}\right] *(E b p 1+\text { Emi1 + Ema1), }
$$

where, $\Delta I_{f^{-}}$the aggregate intensification of corporate finances depending on changes in their direct efficiency without regard to its differentiation, rubles;

$\mathrm{CP}_{1}$ - total profit of corporations in the reporting period of time, rubles;

$\mathrm{E}_{\mathrm{bp1} 1}$ - costs of corporations to conduct their economic processes in the reporting period of time, rubles;

$E_{\text {mil }}$ - expenses of corporations for adaptation to the conditions of the microenvironment of their activities in the reporting period, rubles;

$E_{m a 1}-$ expenses of corporations for adaptation to the conditions of the macroenvironment of their activities in the reporting period, rubles;

$\mathrm{C}_{0^{-}}$the total profit of corporations in the reference period of time, rubles; 
$E_{b p 0}$ - expenses of corporations for conducting business processes by them in the reference period of time, rubles;

$\mathrm{E}_{\mathrm{mi}}$ - expenses of corporations for adaptation to the conditions of the microenvironment of their activities in the reference period of time, rubles;

$E_{m a 0}$ - expenses of corporations for adaptation to the conditions of the macroenvironment of their activities in the reference period of time, rubles;

$$
\Delta I_{d}=\left(\frac{1}{\Delta \mathrm{Ebp} / \Delta P}+\frac{1}{\Delta \mathrm{Emi} / \Delta P}+\frac{1}{\Delta E m a / \Delta P}\right) *(\mathrm{Ebp} 1+\mathrm{Emi} 1+\mathrm{Ema} 1),
$$

where $\Delta I_{d}$ - total intensification of corporate finances depending on changes in their direct efficiency, taking into account its differentiation, rubles;

$\frac{1}{\Delta \mathrm{Ebp} / \Delta p}$ - change in the direct efficiency of corporate finances in terms of expenditures on economic processes in the reporting period compared to the base period of time;

$\frac{1}{\Delta \mathrm{Emi} / \Delta p}$ - the change in the direct efficiency of corporate finance on the costs of adapting to the micro-environment of activity in the reporting period compared to the base period of time;

$\frac{1}{\triangle E m a / \Delta p}$ - the change in the direct efficiency of corporate finance on the costs of adapting to the macro environment of activity in the reporting period compared to the base period of time;

$\mathrm{E}_{\mathrm{bp1}}$-expenses of corporations for their business processes in the reporting period, rubles;

$E_{\text {mi1 }}$ - expenses of corporations for adaptation to the conditions of the microenvironment of their activities in the reporting period, rubles;

$E_{\text {mal }}$ - expenses of corporations for adaptation to the conditions of the macroenvironment of their activities in the reporting period, rubles;

$$
\Delta I_{f}=\left[\frac{E b p 1+E_{m i 1}+\mathrm{P}_{\mathrm{ma1}}}{T P_{1}}-\frac{E_{b p 0}+E_{m i 0}+E_{m a 0}}{T P_{0}}\right] * T P_{1},
$$

where, $\Delta I_{f^{-}}$is the total intensification of corporate finance depending on changes in their indirect efficiency without taking into account its differentiation, rubles;

$E_{b p 1}$ - expenses of corporations for their business processes in the reporting period, rubles;

$E_{\text {mil }}$ - expenses of corporations for adaptation to the conditions of the microenvironment of their activities in the reporting period, rubles;

$E_{\text {mal }}$ - expenses of corporations for adaptation to the conditions of the macroenvironment of their activities in the reporting period, rubles;

$\mathrm{E}_{\mathrm{bp} 0}$ - expenses of corporations for conducting business processes by them in the reference period of time, rubles;

$\mathrm{E}_{\mathrm{mi}}$ - expenses of corporations for adaptation to the conditions of the microenvironment of their activities in the reference period of time, rubles;

$E_{\mathrm{ma} 0}$ - expenses of corporations for adaptation to the conditions of the macroenvironment of their activities in the reference period of time, rubles;

$\mathrm{TP}_{0}$ - is the total profit of corporations in the reference period of time, rubles;

$$
\Delta I_{f}=\left(\frac{1}{\Delta P / \Delta E_{b p}}+\frac{1}{\Delta P / \Delta E_{m i}}+\frac{1}{\Delta P / \Delta E_{m a}}\right) *\left[\left(I_{b 1}-E_{b 1}\right)+\left(I_{s 1}-E_{s 1}\right)\right],
$$

where $\Delta I_{f}$ - is the total intensification of corporate finance depending on changes in their indirect efficiency,

taking into account its differentiation, rubles; 
$\frac{1}{\Delta P / \Delta E_{b p}}$ - change in the indirect efficiency of corporate finance in terms of the costs of conducting business processes in the reporting period compared to the base period;

$\frac{1}{\Delta P / \Delta E_{m i}}$ - change in the indirect efficiency of corporate finance in terms of the costs of adaptation to the microenvironment of activities in the reporting period compared to the base period;

$\frac{1}{\Delta P / \Delta E_{m a}}$ - change in the indirect efficiency of corporate finance in terms of the costs of adaptation to the macroenvironment of activity in the reporting period compared to the base period;

$\mathrm{IB}_{1}$ - income of corporations from basic activities in the reporting period, rubles;

$\mathrm{EB}_{1}$ - expenses of corporations from basic activities in the reporting period, rubles;

$\mathrm{I}_{\mathrm{S} 1}$ - income of corporations from supporting activities in the reporting period, rubles;

$E_{1}$ - expenses of corporations from supporting activities in the reporting period, rubles.

The characteristics of the indicators of the intensification of corporate finance without taking into account and taking into account the differentiation of their direct and indirect efficiency are given, respectively, in Table 1.

Table 1. Characteristics of indicators of intensification of corporate finance.

\begin{tabular}{|c|c|c|}
\hline № & Indicators & Contents \\
\hline \multicolumn{3}{|c|}{ Depending on the change in their efficiency without regard to its differentiation } \\
\hline 1 & $\begin{array}{l}\text { Aggregate direct intensification of } \\
\text { corporate finance depending on changes } \\
\text { in their direct efficiency without taking } \\
\text { into account its differentiation }\end{array}$ & $\begin{array}{l}\text { Increase (decrease) in corporate profits as a } \\
\text { result of an increase (decrease) in the direct } \\
\text { generalized profitability of their activities }\end{array}$ \\
\hline 2 & $\begin{array}{l}\text { Aggregate indirect intensification of } \\
\text { corporate finance depending on changes } \\
\text { in their indirect efficiency without taking } \\
\text { into account its differentiation }\end{array}$ & $\begin{array}{l}\text { Decrease (increase) of expenses of corporations } \\
\text { under the influence of decrease (increase) of } \\
\text { indirect generalized profitability of their } \\
\text { activity }\end{array}$ \\
\hline \multicolumn{3}{|c|}{ Depending on the change in their efficiency, taking into account its differentiation } \\
\hline 3 & $\begin{array}{l}\text { Cumulative intensification of corporate } \\
\text { finances depending on changes in their } \\
\text { direct efficiency, taking into account its } \\
\text { differentiation }\end{array}$ & $\begin{array}{l}\text { Increase (decrease) in corporate profits as a } \\
\text { result of an increase (decrease) in the direct } \\
\text { detailed profitability of the costs of economic } \\
\text { processes, the costs of adapting to the micro } \\
\text { and macro environment of their activities and } \\
\text { the basic and reinforcing profits they receive }\end{array}$ \\
\hline 4 & $\begin{array}{l}\text { Cumulative intensification of corporate } \\
\text { finance depending on changes in their } \\
\text { indirect efficiency, taking into account its } \\
\text { differentiation }\end{array}$ & $\begin{array}{l}\text { Decrease (increase) in corporate expenses } \\
\text { under the influence of a decrease (increase) in } \\
\text { the mediated detailed profitability in terms of } \\
\text { the costs of conducting business processes, the } \\
\text { costs of adapting to the microenvironment and } \\
\text { the macroenvironment of their activities and the } \\
\text { basic and supporting profits they receive }\end{array}$ \\
\hline
\end{tabular}

The table shows that the indicators interpreted in it (line 1 and 2) refer to formulas (3), (5) and are used to analyze the intensification of corporate finance in general and to determine the general dynamics of development of financial relations of corporations. And 3 and 4 lines of the table, refer to formulas (4), (6) and are used for the analysis of its separate indicators (direct and indirect profitability of corporations on expenses on conducting economic processes, expenses on adaptation to microenvironment and macroenvironment of their activity) and search of reserves on optimization of their financial benefit. 


\section{Results}

When forming indicators of corporate finance efficiency, two important economic circumstances must be taken into account. First, the activities of many corporations, as a rule, go beyond national borders (most of them have contracts with foreign partners), and secondly, big business is inevitably faced with the need to attract borrowed capital.

Taking into account these circumstances, let us build dependences between the generalized resulting and factor indicators of corporate finance efficiency:

$$
E F_{c f(d)}=\frac{\boldsymbol{P}_{n}+\boldsymbol{P i}}{\boldsymbol{C C}+\boldsymbol{C B}}
$$

where $E F_{c f(d)}$ is the direct efficiency of corporate finance;

$\mathrm{Pn}$ - profit from national economic transactions, rubles;

$\mathrm{Pi}$ - profit from international business transactions, rubles;

$\mathrm{CC}$ - consumed equity capital (capital and reserves), rubles;

$\mathrm{CB}$ - consumed borrowed capital, rubles;

$$
E F_{c f(c)}=\frac{C C+C B}{P n+P i},
$$

where $E F_{c f(c)}$ is the indirect efficiency of corporate finance;

Pn- profit from national economic transactions, rubles;

$\mathrm{Pi}$ - profit from international business transactions, rubles;

$\mathrm{CC}$ - consumed equity, rubles;

CB - consumed borrowed capital, rubles.

The activities of corporations on a national and international scale include profits from operating (core) and investing activities. Investment activities include investments in fixed assets (real assets) and securities, including debt securities (bonds, promissory notes), contributions to charter capitals of other organizations, loans provided, etc. (financial investments), as well as the implementation of practical actions to achieve their goals. (financial investments) as well as the implementation of practical actions to achieve its goals.

Borrowed capital represents long-term and short-term liabilities. Together with equity, it is subject to consumption. Having decomposed numerator and denominator of formulas (7), (8), we receive identical in sense detailed indices of efficiency of corporate finances:

$$
E F_{c f(d)}=\frac{\left(\boldsymbol{P}_{n(o a)}+\boldsymbol{P}_{n(r i)}+\boldsymbol{P}_{n(f i)}\right)+\left(\boldsymbol{P}_{i(o a)}+\boldsymbol{P}_{i(r i)}+\boldsymbol{P}_{i(f i)}\right)}{\left(\mathrm{CR}_{n}+\mathrm{CLn}+\mathrm{CSn}\right)+(\mathrm{CRi}+\mathrm{CLi}+\mathrm{CSi})},
$$

where $E F_{c f(d)}$ is the direct efficiency of corporate finance;

$\mathrm{P}_{\mathrm{n}(\mathrm{oa})}$ - profit from national operating activities, rubles;

$\mathrm{P}_{\mathrm{n}(\mathrm{ri})}$ - profit from national real investments, rubles;

$\mathrm{P}_{\mathrm{n}(\mathrm{fi})}$ - profit from national financial investments, rubles;

$\mathrm{P}_{\mathrm{i} \text { (oa) }}$ - profit from international operating activities, rubles;

$\mathrm{P}_{\mathrm{i}(\mathrm{ri})}$ - profit from international real investments, rubles;

$P_{n(f i)}$ - profit from international financial investments, rubles;

$\mathrm{CR}_{\mathrm{n}}$ - consumed capital and reserves in the field of national economic operations, rubles;

$\mathrm{CL}_{\mathrm{n}}$ - consumed long-term liabilities in the field of national economic operations, rubles;

CSn - consumed short-term liabilities in the field of national economic transactions, rubles;

$\mathrm{CRi}$ - consumed capital and reserves in the field of international business transactions, rubles; 
CLi - consumed long-term liabilities in the field of international business transactions, rubles;

CSi - consumed short-term liabilities in the field of international business transactions, rubles;

$$
E F_{c f(c)}=\frac{(\mathrm{CRn}+\mathrm{CLn}+\mathrm{CSn})+(\mathrm{CRi}+\mathrm{CLi}+\mathrm{CSi})}{\left(\boldsymbol{P}_{\mathrm{N}(\mathrm{oa})}+\boldsymbol{P}_{\mathrm{N}(\mathrm{ri})}+\boldsymbol{P}_{\mathrm{N}(\mathrm{fi})}\right)+\left(\boldsymbol{P}_{\mathrm{I}(\mathrm{oa})}+\boldsymbol{P}_{\mathrm{I}(\mathrm{ri})}+\boldsymbol{P}_{\mathbf{I}((\mathrm{fi}))}\right)},
$$

where $E F_{c f(c)}$ is the indirect efficiency of corporate finance;

$\mathrm{CR}_{\mathrm{n}}$ - consumed capital and reserves in the field of national economic operations, rubles;

$\mathrm{CL}_{\mathrm{n}}$ - consumed long-term liabilities in the field of national economic operations, rubles;

$\mathrm{CS}_{\mathrm{n}}$ - consumed short-term liabilities in the field of national economic transactions, rubles;

$\mathrm{CR}_{\mathrm{i}}$ - consumed capital and reserves in the field of international business transactions, rubles;

$\mathrm{CL}_{\mathrm{i}}$ - consumed long-term liabilities in the field of international business transactions, rubles;

$\mathrm{CS}_{\mathrm{i}}$ - consumed short-term liabilities in the field of international business transactions, rubles;

$\mathrm{PN}_{(\mathrm{oa})}$ - profit from national operating activities, rubles;

$\mathrm{PN}_{(\mathrm{ri})}$ - profit from national real investments, rubles;

$\mathrm{PN}_{(\mathrm{fi})}$ - profit from national financial investments, rubles;

$\mathrm{Pi}_{(\text {oa) }}$ - profit from international operating activities, rubles;

$\mathrm{PI}_{(\mathrm{ri})}$ - profit from international real investments, rubles;

$\mathrm{PI}_{(\mathrm{fi})}$ - profit from international financial investments, rubles.

Intensification is a change in results and costs depending on changes in direct and indirect efficiency. Based on this definition, first generalized (Table 2) indicators of the intensification of corporate finance were developed, and then detailed ones (Table 3), which allow a more accurate assessment of the efficiency of enterprises.

Table 2. Generalized indicators of corporate finance intensification.

\begin{tabular}{|c|c|c|}
\hline $\begin{array}{l}\mathbf{N o} \\
\mathbf{p} / \mathbf{p}\end{array}$ & Formula & Purpose and concept \\
\hline \multirow[t]{3}{*}{1} & $\begin{array}{l}\operatorname{In}_{c f(d)}=d\left[\frac{P n+P i}{C C+C B}\right] * \int \Sigma(\Delta C C+ \\
\Delta C B) d x\end{array}$ & $\begin{array}{l}\text { where } \operatorname{In}_{c f(d)} \text { - direct intensification of corporate } \\
\text { finances (generalized increase or generalized } \\
\text { decrease in aggregate profit depending on the } \\
\text { generalized change (increase or decrease) in the } \\
\text { direct efficiency of corporate finances in the } \\
\text { reporting period compared with the base period), } \\
\text { rubles. }\end{array}$ \\
\hline & \multicolumn{2}{|c|}{$\begin{array}{l}\text { - change (generalized positive or negative increment) in the direct efficiency } \\
\text { e finances in the reporting period compared to the base period }\end{array}$} \\
\hline & \multicolumn{2}{|c|}{$\begin{array}{l}\int \Sigma(\triangle C C+\triangle C B) d x-\text { initial (generalized first-form) amount of consumed total capital } \\
\text { (sum of own and borrowed capital), rubles. }\end{array}$} \\
\hline 2 & 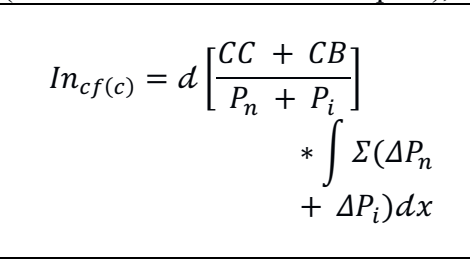 & $\begin{array}{l}\text { where } \operatorname{In}_{c f(j)} \text { - indirect intensification of corporate } \\
\text { finances (generalized increase or generalized } \\
\text { decrease in the amount of aggregate capital } \\
\text { consumption, depending on the generalized } \\
\text { change (increase or decrease) in the indirect } \\
\text { efficiency of corporate finances in the reporting } \\
\text { period compared to the base period) }\end{array}$ \\
\hline
\end{tabular}




\begin{tabular}{|l|l|}
\hline & $\begin{array}{l}d\left[\frac{C C+C B}{P_{n}+P_{i}}\right]-\text { change (generalized positive or negative increment) of indirect efficiency of } \\
\text { corporate finances in the reporting period compared to the reference period }\end{array}$ \\
\cline { 2 - 3 } & $\begin{array}{l}\int \sum\left(\Delta P_{n}+\Delta P_{i}\right) d x-\text { initial (generalized primitive) total profit (the amount of profit from } \\
\text { national and international business transactions), rub. }\end{array}$ \\
\hline
\end{tabular}

Table 3. Detailed indicators of corporate finance intensification.

\begin{tabular}{|c|c|c|}
\hline $\begin{array}{l}\text { № } \\
\mathbf{p} / \mathbf{p}\end{array}$ & $\begin{array}{c}\text { Formula / } \\
\text { Purpose and } \\
\text { concept }\end{array}$ & Intensification indicator \\
\hline \multirow{6}{*}{1} & Formula & $\begin{array}{l}\mathrm{In}_{\mathrm{cf}(d)}=d\left[\frac{\left(\mathrm{P}_{\mathrm{N}(\mathrm{oa})}+\mathrm{P}_{\mathrm{N}(\mathrm{ri})}+\mathrm{P}_{\mathrm{N}(\mathrm{fi})}\right)+\left(\mathrm{P}_{\mathrm{I}(\mathrm{oa})}+\mathrm{P}_{\mathrm{I}(\mathrm{ri})}+\mathrm{P}_{\mathrm{I}(\mathrm{fi})}\right.}{\left(\mathrm{CR}_{\mathrm{n}}+\mathrm{CL}_{\mathrm{n}}+\mathrm{CS}_{\mathrm{n}}\right)+\left(\mathrm{CR}_{\mathrm{i}}+\mathrm{CL}_{\mathrm{i}}+\mathrm{CS}_{\mathrm{i}}\right)}\right] * \int \Sigma(\Delta \mathrm{CR}+\Delta \mathrm{CL}+ \\
\Delta \mathrm{CS}) d \mathrm{X}\end{array}$ \\
\hline & $\begin{array}{l}\text { Purpose and } \\
\text { concept }\end{array}$ & $\begin{array}{l}\text { where } \operatorname{In}_{\mathrm{cf}}(\mathrm{p}) \text { is the direct intensification of corporate finance (a detailed } \\
\text { increase or a detailed decrease in total profit depending on the detailed } \\
\text { change (increase or decrease) in the direct efficiency of corporate finance } \\
\text { in the reporting period, compared to the baseline), rubles. }\end{array}$ \\
\hline & Formula & $d\left[\frac{\left(\mathrm{P}_{\mathrm{N}(\mathrm{oa})}+\mathrm{P}_{\mathrm{N}(\mathrm{ri})}+\mathrm{P}_{\mathrm{N}(\mathrm{fi})}\right)+\left(\mathrm{P}_{\mathrm{I}(\mathrm{oa})}+\mathrm{P}_{\mathrm{I}(\mathrm{ri})}+\mathrm{P}_{\mathrm{I}(\mathrm{fi})}\right.}{\left(\mathrm{CR}_{\mathrm{n}}+\mathrm{CL}_{\mathrm{n}}+\mathrm{CS}_{\mathrm{n}}\right)+\left(\mathrm{CR}_{\mathrm{i}}+\mathrm{CL}_{\mathrm{i}}+\mathrm{CS}_{\mathrm{i}}\right)}\right]$ \\
\hline & $\begin{array}{l}\text { Purpose and } \\
\text { concept }\end{array}$ & $\begin{array}{l}\text { change (detailed positive or negative increment) in the direct efficiency of } \\
\text { corporate finance in the reporting period compared to the baseline }\end{array}$ \\
\hline & Formula & $\Sigma(\Delta \mathrm{CR}+\Delta \mathrm{CL}+\Delta \mathrm{CS}) d \mathrm{x}$ \\
\hline & $\begin{array}{l}\text { Purpose and } \\
\text { concept }\end{array}$ & $\begin{array}{l}\text { initial (detailed first-form) amount of consumed total capital (the sum of } \\
\text { capital and reserves, long-term and short-term liabilities), rubles. }\end{array}$ \\
\hline \multirow{6}{*}{2} & Formula & $\begin{array}{c}\operatorname{In}_{\mathrm{cf}(\mathrm{c})}=d\left[\frac{\left(\mathrm{CR}_{\mathrm{n}}+\mathrm{CL}_{\mathrm{n}}+\mathrm{CS}_{\mathrm{n}}\right)+\left(\mathrm{CR}_{\mathrm{i}}+\mathrm{CL}_{\mathrm{i}}+\mathrm{CS}_{\mathrm{i}}\right)}{\left(\mathrm{P}_{\mathrm{N}(\mathrm{oa})}+\mathrm{P}_{\mathrm{N}(\mathrm{ri})}+\mathrm{P}_{\mathrm{N}(\mathrm{fi})}\right)+\left(\mathrm{P}_{\mathrm{I}(\mathrm{oa})}+\mathrm{P}_{\mathrm{I}(\mathrm{ri})}+\mathrm{P}_{\mathrm{I}(\mathrm{fi})}\right.}\right] \\
* \int \sum\left(\Delta \mathrm{P}_{(\text {oa })}+\Delta \mathrm{P}_{(\mathrm{ri})}+\Delta \mathrm{P}_{(\mathrm{fi})}\right) d \mathrm{x}\end{array}$ \\
\hline & $\begin{array}{l}\text { Purpose and } \\
\text { concept }\end{array}$ & $\begin{array}{l}\text { where } I_{n c f(c)} \text { - indirect intensification of corporate finances (detailed } \\
\text { increase or detailed decrease in the amount of aggregate capital } \\
\text { consumption, depending on changes (increase or decrease) in the indirect } \\
\text { efficiency of corporate finances in the reporting period compared to the } \\
\text { base period), rubles. }\end{array}$ \\
\hline & Formula & $\begin{array}{lll}I & I(o a) & I\end{array}$ \\
\hline & $\begin{array}{l}\text { Purpose and } \\
\text { concept }\end{array}$ & $\begin{array}{l}\text { change (detailed positive or negative increment) in the indirect efficiency } \\
\text { of corporate finance in the reporting period compared to the baseline }\end{array}$ \\
\hline & Formula & $\Sigma\left(\Delta \mathrm{P}_{(\text {oa })}+\Delta \mathrm{P}_{(\mathrm{ri})}+\Delta \mathrm{P}_{(\mathrm{fi})}\right) d \mathrm{x}$ \\
\hline & $\begin{array}{l}\text { Purpose and } \\
\text { concept }\end{array}$ & $\begin{array}{l}\text { initial (detailed primitive) total profit (the amount of profit from national } \\
\text { and international operating activities, real and financial investments), rub. }\end{array}$ \\
\hline
\end{tabular}

In order to check the possibility of using the proposed formulas, calculations of the efficiency and intensification of the finances of a particular corporation were carried out (table 4). The analyzed period covered 5 years (this time interval is considered objective for the evaluation of the discussed parameters). The indicators in the initial and final years were compared. 
Table 4. Evaluation of the effectiveness and intensification of corporate finance LLC «Komos Group».

\begin{tabular}{|l|c|c|c|c|}
\hline \multicolumn{1}{|c|}{ Indicators } & 2015 year. & 2019 year. & \multicolumn{2}{c|}{ Change } \\
\cline { 4 - 5 } & 51286385 & 45537156 & -5749229 & -11.21 \\
\hline $\begin{array}{l}\text { Aggregate income. thousand } \\
\text { rubles. }\end{array}$ & 47994554 & 44072335 & -3922219 & -8.17 \\
\hline $\begin{array}{l}\text { Aggregate expenditures. thousand } \\
\text { rubles. }\end{array}$ & 3291831 & 1464821 & -1827010 & -55.5 \\
\hline Aggregate profit. thousand rubles. & 9681856 & 48827367 & 39145511 & 404.32 \\
\hline $\begin{array}{l}\text { Consumable capital. thousand } \\
\text { rubles. }\end{array}$ & 8394169 & 47538325 & 39144156 & 466.33 \\
\hline Including capital and reserves & 691285 & 659169 & -32116 & -4.65 \\
\hline long-term liabilities & 596402 & 629873 & 33471 & 5.61 \\
\hline short-term liabilities & 0.34 & 0.03 & -0.31 & -91.18 \\
\hline $\begin{array}{l}\text { Direct efficiency of corporate } \\
\text { finance }\end{array}$ & 2.94 & 34.21 & 31.27 & 1063.61 \\
\hline $\begin{array}{l}\text { Indirect efficiency of corporate } \\
\text { finance }\end{array}$ & 2.55 & 33.33 & 30.78 & 1207.06 \\
\hline $\begin{array}{l}\text { including consumed capital and } \\
\text { reserves }\end{array}$ & 0.21 & 0.45 & 0.24 & 114.29 \\
\hline consumed long-term liabilities & 0.18 & 0.43 & 0.25 & 138.89 \\
\hline consumed short-term liabilities & $\mathrm{x}$ & -15136484 & $\mathrm{x}$ & $\mathrm{x}$ \\
\hline $\begin{array}{l}\text { Direct intensification of corporate } \\
\text { finance. thousand rubles }\end{array}$ & 45804953 & $\mathrm{x}$ & $\mathrm{x}$ \\
\hline $\begin{array}{l}\text { Indirect intensification of corporate } \\
\text { finance. thousand rubles }\end{array}$ & $\mathrm{x}$ & & \\
\hline
\end{tabular}

The results of the calculations indicate a low level of efficiency and intensification of the finances of the corporation under study, which is associated with a significant decrease in the effectiveness (direct profitability) of its activities as a whole and on individual elements of consumed capital. First of all, it is caused by a sharp reduction in the degree of return on equity due to the rapid growth of their cost. Thus similar parameters on long-term and short-term borrowings are also at critical level. The current negative trend had a negative impact on direct and indirect corporate intensification, because the deterioration of direct and indirect corporate efficiency indicators resulted in a 15136484 thousand rubles of profit losses and a 45804953 thousand rubles of capital overrun. Due to the above, the corporation urgently needs to develop measures aimed primarily at saving capital and reserves with a simultaneous increase in its productivity.

The proposals developed by the authors correspond to the modern economic situation and the economic nature of the categories of «efficiency» and «intensification. They allow not only to reveal the dependence between the resultant and factor indicators, but also to analyze the interaction of the factor indicators themselves of the first and other orders. On the basis of the analysis of these indicators it is possible to obtain complete, reliable and comprehensive information about corporate finance.

\section{Discussion}

One of the stages of formation of the system of indicators of intensification of corporate finances is budgeting. The budgeting system, using the possibilities of modern information technologies, gives an opportunity to carry out internal economic control and multivariate analysis of financial results from realization of the adopted budgets, forms conditions for analysis of various scenarios of transformation of financial condition, assessment of financial stability in permanently changing conditions of external economic environment 
[32-36]. During budgeting, budgets for the upcoming period, reports on their implementation for the past time are prepared, and the planned and actual indicators are compared. This allows for the so-called analysis of deviations, i.e. assessment of the level of deviation of actual indicators from the planned ones and the reasons for their occurrence.

The tools of budgeting include zero-based budgeting - a method of budgeting, in which all costs must be justified for each new period. In contrast to incremental budgeting, the planned level of expenses does not depend on its previous values, i.e. all expenses in the base period are zero and require a new, completely independent definition. The system of zero-based budgeting provides an opportunity for regular reevaluation of activities and programs in comparison with new projects, based on the criteria of comparison of expected results and future costs. The value of this system consists in timely decision-making on restructuring on the basis of the most reasonable financial calculations in case of economic instability and increased uncertainty, and also the termination of financing of those projects and programs, efficiency of future results of which is doubtful.

The system of zero-based budgeting based on the principle of «distribution of resources on a zero basis», which became widespread in the American practice in the early 1960s, allows for periodic (usually once a year) reassessment of the ongoing activities and programs (construction, $\mathrm{R} \& \mathrm{D}$, etc.) in comparison with newly proposed projects.

Basic principles of zero-based budgeting system functioning are as follows: several mutually exclusive directions of goal achievement are considered; to achieve the goals in the most optimal way different levels of spending of decision-making centers are justified taking into account their activity using incremental decision packages; decision packages for different decision-making centers are distributed taking into account limitations on the amount of required resources and goals of the organization.

Zero-based budgeting is a way to rationalize the processes of allocating limited (usually investment) resources and corresponding continuous adjustments to previously formed budgets. The differences are only in the fact that the usual rolling financial planning system is based on the constancy of budget estimates for the entire budget period, on the results achieved, levels of financing of investment and current costs. Within the ZBB, in the event of a change in the ranking criteria, it is possible to refuse funding for a project or its individual articles.

Activity based budgeting is an approach to budgeting using activity-based costing concepts. Action budgeting uses information about the relationship between items of production and the activities required to produce those items to develop detailed estimates of the needs for the activities that form the basis of the recommended production plan.

Performance budgeting is a methodology for preparing and executing a budget, in which cost planning is carried out in direct connection with the results achieved.

The methods of analyzing costs, output and production results, which are one of the stages in the formation of a system of indicators for the intensification of corporate finance, include CVP analysis, XYZ analysis, and variance analysis.

CVP-analysis (cost-volume-profit) is one of the most effective methods of marginal analysis, resource allocation by product type and decision-making on production, provision, performance of work. In the literature, there are other names for this procedure, for example: «method of critical sales volume», «method of determining the dead center», «method of zero profit point», «operational analysis», «margin method», method «cost volume - profit», break-even analysis.

Break-even analysis is an effective tool of planning and management decision-making in the corporation. The base for making decisions about production activity is the study of options of probable changes in the market situation. Since the plan of the organization acts as a system of values of indicators, which the organization is going to achieve in the future, its implementation will depend on many different factors. In the process of planning the 
management of the organization must solve the following problems: to establish the volume of production, which not only compensates the costs, but also will give the opportunity to get the desired profit; to determine the price of the products produced; to set the value of costs, giving the opportunity to remain competitive in the market.

$\mathrm{XYZ}$-analysis is a tool of inventory management, which is used to develop the logistics system of the organization and is used in conjunction with $\mathrm{ABC}$-analysis, which makes it possible to determine the main goods for the organization. It is an analysis of the stability of sales of individual products in the assortment of the enterprise and examines deviations, jumps, instability of sales. The purpose of XYZ-analysis is to divide goods in the assortment into groups depending on the accuracy of forecasting and uniformity of demand.

Category $\mathrm{X}$ is a group characterized by a fairly stable level of use and high accuracy of forecasting the period of consumption. In particular, if we are talking about materials, there are consumption rates for each type of material. Category $\mathrm{Y}$ includes resources characterized by seasonality in use and average forecasting capabilities. Category $\mathrm{Z}$ includes resources that are used irregularly, the amount of consumption of which is difficult to predict.

In our opinion, the analysis of deviations is of no small importance in the complex of analytical works in corporations. As a rule, deviations arise as a result of changes in the three most significant factors: prices for resources, norms of consumption per unit and output volume of production. The basic indicators on which deviations of actual and planned values can arise are: cost indicators - costs, marginal profit, income from turnover, payments, receipts, accounts payable and accounts receivable, capital, etc.; indicators of organizational structure - places of origin of costs, production, sales, design units, etc.; temporal indicators - days, weeks, months, quarters, years.

The literature distinguishes the following types of deviations:

1. Absolute deviations are the difference that results from subtracting one value from another, which characterizes the status quo between the actual and planned data;

2. Relative deviations are calculated in relation to other values and are expressed as a percentage.

3. Selective deviations imply comparison of controlled values in a time section: a quarter, a month and sometimes a day.

4. Cumulative deviation. Amounts that are calculated cumulatively (cumulative amounts) and their deviations make it possible to assess the degree of achievement for past periods (months) and the potential difference by the end of the planned period (year).

5. Deviations in the time section are determined on the basis of comparison of the budgeted and actually obtained values of the monitored parameters.

The resulting deviations must be weighted according to certain criteria:

1. Assessment by tolerance limits. For the purpose of assessing selective deviations, as a rule, linear limits defined either in absolute values or in percentages are applied. For cumulative deviations non-linear limits are used, which have a graphical representation in the form of a funnel, tapering by the end of the planned period;

2. The size of a percentage deviation of an individual parameter primarily indicates the quality of planning and budgetary discipline, but says practically nothing about the degree of influence on profit. This approach implies ranking the parameters that affect profit, both in positive and negative directions.

\section{Conclusions}

The developed approach to the formation of indicators of efficiency and intensification of corporate finance has several advantages. In particular, it corresponds to the current financial-economic and financial-management realities. The proposed factor indicators 
(profit and consumed capital) are reduced to a single time interval. A clear differentiation of the elements of the result and costs of the enterprise is carried out. On the basis of such approach it is possible to keep complex and systematic accounting of factor indicators. Besides, there is a possibility of clear ranking of reserves, improvement of productivity and reduction of expenses of enterprise projects. Realization of the listed advantages will allow corporations to optimize their activity and increase their competitiveness in their market segments in the long term.

The proposed toolkit corresponds to the current economic conditions, characterized by the multi-vector financial relations of modern corporations. With its use, you can maximize financial benefits through an objective analysis of the efficiency and intensification of business operations. As a result, this will contribute to strengthening the economic potential of the corporation in all spheres and areas of activity at the national and international levels.

\section{References}

1. R. Kabir, Journal of Banking \& Finance 36, 2865-2867 (2012) https://doi.org/10.1016/j.jbankfin.2012.04.023

2. S. Ullah, K. Adams, D. Adams, R. Attah-Boakye, Journal of Environmental Management 280, 111689 (2021) https://doi.org/10.1016/j.jenvman.2020.111689

3. L. Vigneau, Journal of International Management 26, 100804 (2020) https://doi.org/10.1016/j.intman.2020.100804

4. J. Pla-Barber, A. Botella-Andreu, C. Villar, International Business Review 30, 101773 (2021) https://doi.org/10.1016/j.ibusrev.2020.101773

5. G. Sertsios, Journal of Corporate Finance 64, 101680 (2020) https://doi.org/10.1016/j.jcorpfin.2020.101680

6. J. Ang, Global Finance Journal 22, $100483 \quad$ (2019) https://doi.org/10.1016/j.gfj.2019.100483

7. Dz. Faizrakhmanov, A. Zakirova, G. Klychova et al, E3S Web of Conferences 91, 06004 (2019) https://doi.org/10.1051/e3sconf/20199106004

8. M.R. Moritzen, A. Schandlbauer, Journal of Corporate Finance 65, 101502 (2020) https://doi.org/10.1016/j.jcorpfin.2019.101502

9. A. Zakirova, G. Klychova, G. Ostaev, et al, E3S Web of Conferences 164, 10009 (2020) https://doi.org/10.1051/e3sconf /202016410009

10. P. Wetzel, E. Hofmann, International Journal of Production Economics 216, 364-383 (2019) https://doi.org/10.1016/j.ijpe.2019.07.001

11. S.K. Nguyen, X.V. Vo, T.M.T. Vo, Heliyon 6, e03788 (2020) https://doi.org/10.1016/j.heliyon.2020.e03788

12. Ch.-Ch. Lee, Sh. Xiao, Economic Modelling 94, 539-547 (2021) https://doi.org/10.1016/j.econmod.2020.01.022

13. B. Yuan, J. Li, G. Zeng, International Journal of Hospitality Management 74, 40-44 (2018) https://doi.org/10.1016/j.ijhm.2018.02.023

14. J. Leontieva, E. Zaugarova, G. Klychova et al, MATEC Web of Conferences 170, 01087 (2018) https://doi.org/10.1051/matecconf/201817001087

15. M. Dewally, Y. Shao, Journal of Banking \& Finance 39, 223-239 (2014) https://doi.org/10.1016/j.jbankfin.2013.11.002

16. F. Abraham, J.J. Cortina, S.L. Schmukler, Journal of Banking \& Finance 122, 105987 (2021) https://doi.org/10.1016/j.jbankfin.2020.105987 
17. F. Jiang, Zh. Jiang, K.A. Kim, Journal of Corporate Finance 63, 101309 (2020) https://doi.org/10.1016/j.jcorpfin.2017.12.001

18. E. Brancaccio, G. Fontana, Cambridge Journal of Economics 40(4), 1055-1075 (2016) http://hdl.handle.net/10.1093/cje/bev068

19. Zh. Shuangling, C. Guohua, W. Lijuan, The North American Journal of Economics and Finance 50, 100991 (2019) https://doi.org/10.1016/j.najef.2019.100991

20. G. Klychova, A. Zakirova, R. Mannapova, et al, E3S Web of Conferences 110, 02075 (2019) https://doi.org/10.1051/e3sconf/201911002075

21. K. Naeem, M.C. Li, International Review of Financial Analysis 62, 53-68 (2019) https://doi.org/10.1016/j.irfa.2019.01.003

22. E. Morellec, N. Schürhoff, Journal of Financial Economics 99, 262-288 (2011) https://doi.org/10.1016/j.jfineco.2010.09.003

23. D. Cumming, V. Verdoliva, F. Zhan, Emerging Markets Review 31, 100792 (2020) https://doi.org/10.1016/j.ememar.2020.100792

24. Y. Ayturk, Finance Research Letters 20, 96-103 (2017) https://doi.org/10.1016/j.frl.2016.09.018

25. P.D. Grauwe, E. Gerba, Ensayos sobre Política Económica 35, 78-100 (2017) https://doi.org/10.1016/j.espe.2016.11.002

26. G.S. Chauhan, IIMB Management Review 29, 170-187 (2017) https://doi.org/10.1016/j.iimb.2017.06.002

27. G. Klychova, A. Zakirova, S. Alibekov, et al, Advances in Intelligent Systems and Computing 1258 AISC, 669-686 (2021) https://doi.org/10.1007/978-3-030-574505_58

28. M.R. Silva, Journal of Economic Dynamics and Control 102, 1-28 (2019) https://doi.org/10.1016/j.jedc.2019.03.001

29. A. Zakirova, G. Klychova, K. Mukhamedzyanov et al, Advances in Intelligent Systems and Computing 1258 AISC, 687-707 (2021) https://doi.org/10.1007/978-3-030-574505_59

30. C. Lennox, Z.-T. Wang, X. Wu, Journal of Accounting and Economics 65, 21-40 (2018) https://doi.org/10.1016/j.jacceco.2017.11.011

31. J. Leontieva, G. Klychova, A. Zakirova et al, E3S Web of Conferences 110, 02016 (2019) https://doi.org/10.1051/e3sconf/20191100

32. K. Levillain, B. Segrestin, European Management Journal 37, 637-647 (2019) https://doi.org/10.1016/j.emj.2019.07.002

33. G.S. Klychova, A.R. Zakirova, K.Z. Mukhamedzyanov, M.S. Faskhutdinova, Mediterranean Journal of Social Sciences 5(24), 104-110 (2014) DOI: 10.5901/mjss.2014.v5n24p104

34. S. Massicotte, J.-F. Henri, The British Accounting Review 23, 100953 (2020) https://doi.org/10.1016/j.bar.2020.100953

35. G. Klychova, A. Zakirova, Sh. Khusainov et al, E3S Web of Conferences 164, 10008 (2020) https://doi.org/10.1051/e3sconf/202015704022

36. T. Gonçalves, C. Gaio, Journal of Business Research 124, 603-609 (2021) https://doi.org/10.1016/j.jbusres.2020.10.059 